\title{
新力学モデルの提案とそれによるコンクリートの 遅延弾性現象の解析
}

\author{
宮川邦彦*・渡辺明**
}

\section{1.まえがき}

コンクリート工学における従来の研究はコンクリート を単一物質と見なし，その諸性質に関しても一面的な捕 え方をしてきた。しかしながら近年，複合体に関する研 究が進むにつれて, その概念を広くコンクリート工学の 分野にも適用しようとする研究が多く見られるようにな ってきた。

確かにコンクリートは粒状物質としての細・粗骨材を マトリックスとしての膠質材料（セメント，アスファル 卜，合成樹脂など）で結合した，いわゆる粒状複合体で あり，それら各構成物質の諸特性の相違が複合体として のコンクリートのそれらに重大な影響を及ぼしているこ とは明白である。それゆえ, 特に複合体の変形特性を研 究する一手段として, 各構成物質の変形特性ならびにそ の複合機構を究明することが是非とも必要で, 変形特性 にかかわる特に重要な課題としてはクリープの問題があ る。クリープに関してはこれまで多くの研究者により貴 重な実験結果が示され，その解析に関する考え方につい ても報告されてきたが, 変形機構の複雑さや測定方法な どに難点があり，現在でもなお，その特性を完全に把握 するまでには至っていない。さて，クリープ現象は時間 要素と複合特性とが複雑に絡み合い, しかもマトリック スの変形特性は一般に時間依存性であるため, 単に一つ の変形概念だけでその機構全体を説明することは無理で あるという観点から, 近年, クリープを数種の変形成分 に分離し，その機構を究明しょうとする動向が認められ る。

筆者らも上記の考えに基づき，コンクリートのクリー プを, 可逆成分としての遅延弾性変形と非可逆成分とし ての塑・粘性変形（内部物質間の既存ひびわれとその伝 播による変形, ペースト部の粘性流動および載荷期間中 の硬化反応による変形など）とに大別し, 特に前者に対

\footnotetext{
* 正会員 九州産業大学助教授 土木工学科 工修 ** 正会員 九州工業大学教授 開発土木工学科 工博
}

する実験的研究を進めてきた1)。そして,これら一連の 実験より, 筆者らはコンクリートの遅延弾性変形の発生 原因が複合物質間の弾性係数差に起因寸る応力平衡化現 象によるものであり, その遅延効果はマトリックスの粘 性特性に起因するものであろうと考えるに至った ${ }^{2), 3)}$

本論文はこのような考えに基づき, 粒状複合体内部の 変形機構に関するモデル解析と経時変化に関するレオロ ジ一解析とを組合せ，遅延弾性変形のひずみ一時間曲線 を理論的に求める新しい解析法を試み, 同曲線が顕著に 得られ易いレジンコンクリートに関する若干の実験で本 解析法の妥当性を検討した結果をまとめたものである。

\section{2. 遅延弾性変形の機構とモデル解析}

\section{1 変形機構}

筆者らは 1.においてコンクリートの遅延弾性変形が 複合体内部物質間に生ずる応力平衡化現象に起因する時 間依存変形であろらと述べたが, さて, その変形機構と はどのようなものであろらか。

図一1 はコンクリート 内部の複合状態を示す略 困である。このようにコ ンクリートは骨材粒子の 間隚を膠質材料で充填 し,一体化したものであ るが, それら各構成物 質の弾性係数は一般に相 当な差異を有する。すな わち, 粒状物質としての 骨材の弾性係数は普通

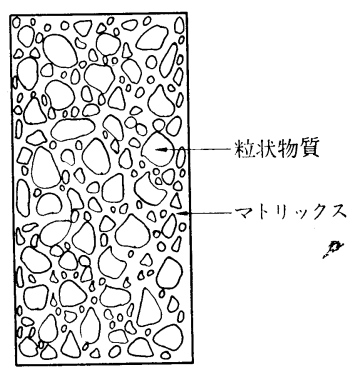

図一1 コンクリートの複合状態 $400000 \sim 800000 \mathrm{~kg} / \mathrm{cm}^{2}$ 程度であるのに対し， マトリ ックスとしてのセメントペーストやレジンペーストのそ れは 50000 200 $000 \mathrm{~kg} / \mathrm{cm}^{2}$ 程度である。このように 大きな弾性係数差を有する粒状複合体に外力が作用した 場合, 各構成物質の応力とひずみとはどのような関係に あるだろらか。いま，各構成物質のひずみが一定である 
とすれば, 構成物質間に応力差を生じ, 複合体全体とし ては内的不安定状態であると考えられ，一方，応力が一 定であるとすれば, 内的には安定状態となるが, 各物質 のひずみが相違するため, 粒状物質とマトリックスとの 間になんらかの相対変位を生じなければならないことに なる。

コンクリート供試体に載荷された直後の状態は, その 応力が供試体破壊強度の $1 / 2$ 以下であれば, その応力ひずみ図からほぼ弾性状態にあると考えられる。すなわ ち, この場合, 時間要素としての粘性流動は生じ得ず, また, 大きな塑性変形も生じないとすれば，各構成物質 のひずみは等しいことになる。しかしながら，その応力 が長期間載荷されると, マトリックスが粘性流動を生 じ,さらに各物質の応力差を減少させるような粒状物質 の回転変位による再配列も進み, 最終的には内的安定な 応力一定状態になるものと考えられないであろうか。

以上の上うな粒状複合体内部の応力ーひずみ状態の経 時変化こそ遅延弾性変形の機構であろらと考え,つぎに 示すモデル解析を試みた。

\section{2 モデル解析}

筆者らはコンクリート内部状態が載荷直後のひずみ一 定状態から, 時間と共に応力一定状態へと移行する間の 変形増大を遅延弾性変形と考え, モデル解析を行った。

な怙, 解析にあたり, コンクリートを粒状物質として の細・粗骨材とマトリックスとしてのペーストからなる 弾性三要素体と考えた。ただし, 厳密にはそれら各物質 自体, さらに高次の複合体と考えるべきであろう。

いま, 単位立方体に応力 $\sigma$ (あるいは荷重 $P$ ) が作用 した直後の変形, すなわち, 弾性変形 $\Delta l_{i}$ はひずみ一定 の関係から式 (1) で求められる。

$$
\Delta l_{i}=\sigma /\left(V_{p} E_{p}+V_{s} E_{s}+V_{g} E_{g}\right)=\sigma / E_{c}
$$

ここに, $E_{c}, E_{p}, E_{s}, E_{g}:$ コンクリート, ペースト, 細骨材および粗骨材の弾性係数。 $V_{p}, V_{s}, V_{g}$ : ペースト, 細骨材および粗骨 材の容積係数。

つぎに, 持続載荷後の応力一定状態における変形 $\Delta l_{n}$ は式 (2) となる。

$$
\Delta l_{n}=\sigma\left(V_{p} / E_{p}+V_{s} / E_{s}+V_{g} / E_{g}\right)
$$

ゆえに, 終局遅延弾性変形 $\Delta l_{\boldsymbol{d}}$ は式 (3) で得られる。 $\Delta l_{d}=\Delta l_{n}-\Delta l_{i}=\sigma\left(V_{p} / E_{p}+V_{s} / E_{s}+V_{g} / E_{g}-1 / E_{c}\right)$

なお, 以上の式における容積係数 $V$ はコンクリート の配合から定まり，また，ペーストの弾性係数 $E_{p}$ も試 的に求めることができるが, 細・粗骨材のそれを直接求 めることは困難である。そこで筆者らは同一配合のコン クリートモルタルおよびペーストの実測弾性係数と前
記のひずみ一定式との関係から, 細・粗骨材の見掛け弾 性係数（骨材内部の既存ひびわれおよびマトリックスと の複合状態の 良否などで真の弾性係数とは異なる。）を それぞれ式 (4), 式 (5) によって求め, それらの值を上 記計算に用いた ${ }^{4)}$ 。

$$
\begin{aligned}
& E_{s}=\left(V_{m} E_{m}-V_{p} E_{p}\right) / V_{s} \\
& E_{g}=\left(E_{c}-V_{m} E_{m}\right) / V_{g}
\end{aligned}
$$

ここに, $E_{m}, V_{m}$ : モルタルの弾性係数および容積係 数

つぎに, 実験值との比較, ならびにコンクリート部材 のクリープ解析への応用を容易にするため, 遅延弾性変 形の表示法として, 任意時間までに生じた遅延弾性変形 を載荷時あるいは除荷時の弾性変形で割った值を遅延弾

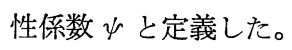

ゆえに，上式の関係から終局遅延弾性係数 $\psi_{n}$ は

$$
\psi_{n}=\Delta l_{d} / \Delta l_{i}=\left(V_{p} / E_{p}+V_{s} / E_{s}+V_{g} / E_{g}\right) E_{c}-1
$$

で求められる。

3. 遅延弾性変形の 経時変化とレオロジー 解析

\section{1 遅延弾性変形の経時変化}

前記のモデル解析では遅延弾性変形の終局值を得るこ としかできず, 任意時間の変形量を求めることはできな い。従来, 遅延弾性変形の経時変化に関しては, 一般に クリープと同様, Voigt 要素と関連づけ, 一つの指数関 数で表示してきた。しかしながら, J.M. Illston はこの 変形が急速に発達する成分と徐々に進行する成分とから 成ると指摘し, モデル解析から各成分の経時変化に対す る解析法を示した ${ }^{5)}$ 。

さて, 実測されたセメントコンクリートの遅延弾性曲 線は, 確かに Illston が指摘したように初期の急激な変 形とその後徐々に増大する変形とから成るため, 単に一 つの指数関数で近似することは極めて困難である。そこ で筆者らは,このような変形曲線の特性と前記の変形機 構とに着目し，モデル解析と直接対応できるような，回 転ダッシュポットを有する新しいレオロジーモデルを考 案し, 遅延弾性変形の経時変化に関する解析を試みた。 以下に，その考え方と解析法を述べる。

\section{2 応力平衡化回転モデルの提案によるレオロジー} 解析

筆者らはさきに遅姃弾性変形が粒状複合体内部での応 力平衡化現象により生ずるものであり, その変形量はひ ずみ一定状態と応力一定状態との差から求められると述 べたが，その関係とモデル解析に用いた要素（構成物質 


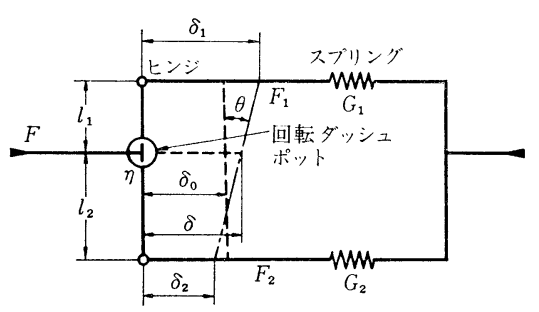

図-2 応力平衡化回転モデル I

の弾性係数と容積係数) とをレオロジ一解析に導入する ため, 図一2 に示す応力平衡化回転モデル（便宜上, 回 転モデルと略称する。）を提案する。

図に示すように回転モデルＩは弾性要素としてのスプ リング (バネ定数 $G_{1}, G_{2}$ ), 粘性要素としての回転ダッ シュポット（粘性係数 ク）ならびにそれらの要素を繋ぐ 腕（腕の長さ $l_{1}, l_{2}$ ) とから成り立っている。

いま，このモデルに外力 $F$ が作用した直後，ダッシ ユポットは回転変位を生じないため, スプリング $G_{1}, G_{2}$ の変形 $\delta_{0}$ は等しい。しかしながら，外力 $F$ が持続され ると,ダッシュポットには回転モーメント $M$ が働くた め，回転ダッシュポットはそのモーメントを低減させる ような回転変位（回転角 $\theta$ ) を生じ始め, 最終的には $M$ $=0$ の状態でこのモデルは安定する。

なお, 図中の実線は無載荷状態を, 破線は載荷直後の 状態を，そして一点鎖線は任意時間 $t$ における状態を示 す。

同モデルに外力 $F$ が作用した場合，任意時間 $t$ にお ける力と適合の条件式は，

(a) 力の釣合い式

$$
F=F_{1}+F_{2}
$$

$F_{1}=\delta_{1} G_{1}$

$F_{2}=\delta_{2} G_{2}$

(b) 適合の条件式

$$
\begin{aligned}
& \theta=\left(\delta_{1}-\delta_{2}\right) /\left(l_{1}+l_{2}\right) \\
& d \theta / d t=\left(l_{2} F_{2}-l_{1} F_{1}\right) / \eta \\
& \delta=\delta_{2}+l_{2} \theta=\left(l_{1} \delta_{2}+l_{2} \delta_{1}\right) /\left(l_{1}+l_{2}\right)
\end{aligned}
$$

である。

式 (10) と式 (11) から $F_{2}$ を消去し, 整理すると,

$$
\theta=\left\{\left(G_{1}+G_{2}\right) F_{1}-G_{1} F\right\} /\left(l_{1}+l_{2}\right) G_{1} G_{2}
$$$$
d \theta / d t=\left\{l_{2} F-\left(l_{1}+l_{2}\right) F_{1}\right\} / \eta
$$

となり，両式の関係から $F_{1}$ に関する微分方程式を得る。

$$
\begin{aligned}
d F_{1} / d t & +\left(l_{1}+l_{2}\right)^{2} G_{1} G_{2} F_{1} / \eta\left(G_{1}+G_{2}\right) \\
- & \left(l_{1}+l_{2}\right) l_{2} G_{1} G_{2} F / \eta\left(G_{1}+G_{2}\right)=0
\end{aligned}
$$

すなわち， $F_{1}$ に関する微分方程式の一般解として

$$
\begin{gathered}
F_{1}=C F e^{\alpha t}+l_{2} F /\left(l_{1}+l_{2}\right) \\
\text { ここ, } \alpha=-\left(l_{1}+l_{2}\right)^{2} G_{1} G_{2} / \eta\left(G_{1}+G_{2}\right)
\end{gathered}
$$

を得る。なお, 積分定数 $C$ は境界条件 $t=0$ で $F_{1}=$ $G_{1} F /\left(G_{1}+G_{2}\right)$ を代入することにより，

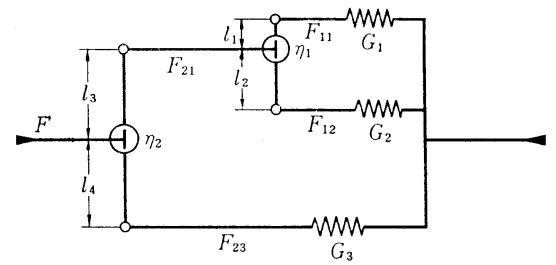

図一3 回転モデル II（弾性三要素体）

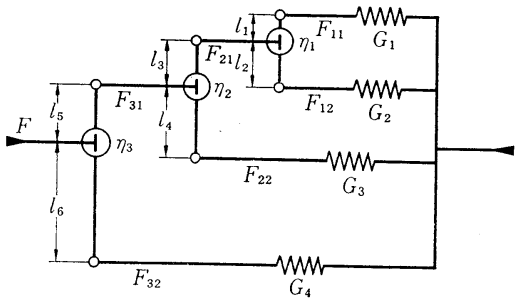

図一4回転モデル III（弾性四要素体）

$$
C=\left(l_{1} G_{1}-l_{2} G_{2}\right) /\left(l_{1}+l_{2}\right)\left(G_{1}+G_{2}\right)
$$

を得る。

つぎに, 式 (12) から $F_{2}$ を消去し, 式 (13) を代入す ると,

$$
\begin{aligned}
\delta= & \left(l_{1}^{2} G_{1}+l_{2}{ }^{2} G_{2}\right) F /\left(l_{1}+l_{2}\right)^{2} G_{1} G_{2} \\
& -\left(l_{1} G_{1}-l_{2} G_{2}\right) C F e^{\alpha t} /\left(l_{1}+l_{2}\right) G_{1} G_{2}
\end{aligned}
$$

となるが，境界条件 $t=0$ で $\delta=\delta_{0}=F /\left(G_{1}+G_{2}\right)$ を代 入し, 整理すると

$$
\begin{aligned}
\delta= & C F\left\{\left(l_{1}+l_{2}\right) l_{2} / \eta+\alpha / G_{2}\right\}\left(1-e^{\alpha t}\right) / \alpha \\
& +F /\left(G_{1}+G_{2}\right)
\end{aligned}
$$

となる。

すなわち，任意時間後の遅延弾性変形 $\delta_{d}$ は

$$
\delta_{d}=\delta-\delta_{0}=C F\left\{\left(l_{1}+l_{2}\right) l_{2} / \eta+\alpha / G_{2}\right\}\left(1-e^{\alpha t}\right) / \alpha
$$

となり,また, 遅延弾性係数注式 (18) で得られる。 $\psi=\delta_{d} / \delta_{0}=\left(G_{1}+G_{2}\right) C\left\{\left(l_{1}+l_{2}\right) l_{2} / \eta+\alpha / G_{2}\right\}\left(1-e^{\alpha t}\right) / \alpha$

さらに，図一3，図一4 に示すように回転モデルI を 組合せたモデルの解析結果を下記に示す。

(a) 回転モデル II (弾性三要素体)

$$
\begin{aligned}
\delta_{d}= & C_{1} F\left\{\left(l_{3}+l_{4}\right) l_{4} / \eta_{2}+\alpha_{1} / G_{3}\right\}\left(1-e^{\alpha_{1} t}\right) / \alpha_{1} \\
& +C_{2} F\left\{\left(l_{3}+l_{4}\right) l_{4} / \eta_{2}+\alpha_{2} / G_{3}\right\}\left(1-e^{\alpha_{2} t}\right) / \alpha_{2} \\
\psi= & \sum G_{i}\left[C_{1}\left\{\left(l_{3}+l_{4}\right) l_{4} / \eta_{2}+\alpha_{1} / G_{3}\right\}\left(1-e^{\alpha_{1} t}\right) / \alpha_{1}\right. \\
& \left.+C_{2}\left\{\left(l_{3}+l_{4}\right) l_{4} / \eta_{2}+\alpha_{2} / G_{3}\right\}\left(1-e^{\alpha_{2} t}\right) / \alpha_{2}\right]
\end{aligned}
$$

ここに, 上式中の係数 $C_{i}$ と $\alpha_{i}$ は力と変形とに関す る境界条件式加定まる定数である。

（b）回転モデル III（弾性四要素体）

$$
\begin{aligned}
\delta_{d}= & D_{1} F\left\{\left(l_{5}+l_{6}\right) l_{6} / \eta_{3}+\beta_{1} / G_{4}\right\}\left(1-e^{\beta_{1} t}\right) / \beta_{1} \\
& +D_{2} F\left\{\left(l_{5}+l_{6}\right) l_{6} / \eta_{3}+\beta_{2} / G_{4}\right\}\left(1-e^{\beta_{2} t}\right) / \beta_{2} \\
& +D_{3} F\left\{\left(l_{5}+l_{6}\right) l_{6} / \eta_{3}+\beta_{3} / G_{4}\right\}\left(1-e^{\beta_{3} t}\right) / \beta_{3}
\end{aligned}
$$




$$
\begin{aligned}
\psi= & \sum G_{i}\left[D_{1}\left\{\left(l_{5}+l_{6}\right) l_{6} / \eta_{3}+\beta_{1} / G_{4}\right\}\left(1-e^{\beta_{1} t}\right) / \beta_{1}\right. \\
& +D_{2}\left\{\left(l_{5}+l_{6}\right) l_{6} / \eta_{3}+\beta_{2} / G_{4}\right\}\left(1-e^{\beta_{2} t}\right) / \beta_{2} \\
& \left.+D_{3}\left\{\left(l_{5}+l_{6}\right) l_{6} / \eta_{3}+\beta_{3} / G_{4}\right\}\left(1-e^{\beta_{3} t}\right) / \beta_{3}\right]
\end{aligned}
$$

上式中の係数 $D_{i}, \beta_{i}$ は同様に, 力と変形とに関する 境界条件式から定まる定数である。

なお，以上の解析は載荷時の状態に関するものであっ たが，いま，その荷重を任意時間後に除去したときの変 形は, Voigt 要素と同様, 重㸚合せの原理から求めるこ とができる。

\section{3 レオロジー解析における要素の取扱い}

従来のレオロジーモデルは実際上の構造要素を意味す るものではなく, 単に時間依存特性を表示するための便 宜的手段として考えられたものである6)。しかしなが ら, 本論文の回転モデルは, 前記のモデル解析との対応 を考慮する場合, モデル要素としてのバネ定数 $G$ が複 合体各物質の弾性係数 $E$ とその容積係数 $V$ との積に, また, 腕の長さ $l$ が容積係数 $V$ に相当すると考えねば ならず, それゆえ, 各要素の值を任意に定めることはで きない。この点, 同モデルは従来のモデルとは全く相違 するものと考えるべきであろう。ただし，時間要素とし ての粘性係数 $\eta$ は実測曲線との対応から求めなければ ならない。

4.レジンコンクリートに関する実験的研 究

筆者らは数年来, セメントコンクリートに関する種々 なクリープ実験を行ってきたが，これら一連の実験で， 特にセメントコンクリートの場合,

（1）ひずみ測定に用いるストレインゲージの付着効 果が劣る。

（2）モールドゲージを用いることは，筆者らの考え る遅延弾性変形の機構上，不適当である。

（3）セメントの水和反応でコンクリート自体の変形 特性が変化する。

（4）実測される変形自体僅少で, 測定誤差の影響を 受けやすい。

（5）載荷履歴を受けた供試体の乾燥収縮と無載荷供 試体のそれとを同一視することに矛盾を感ずる。 などの問題点を含むため, 本実験ではそれらの影響を多 少とも補なえる材料をと考え, 高温養生したレジンコン クリートを用いた。以下に, 実験概要, 結果ならびにレ オロジー解析との比較検討を述べる。

\section{1 実 験 概 要}

\begin{tabular}{|c|c|c|c|c|c|c|c|}
\hline \multicolumn{2}{|c|}{ レジン } & \multicolumn{2}{|c|}{ 岸酸カルシウム粉 } & \multicolumn{2}{|c|}{ 細骨材(海砂) } & \multicolumn{2}{|c|}{ 粗骨材 (角閃岩) } \\
\hline 硬化前 & 硬化後 & 絶 & 乾 & 表 乾 & 絶 乾 & 表 乾 & 絶 乾 \\
\hline 1.11 & 1.21 & & & 2.55 & 2.52 & 2.94 & 2.92 \\
\hline
\end{tabular}

本実験は遅延弹性変形の機構を検討するため, 特に載
表一1 使用材料の比重

\begin{tabular}{|c|c|c|c|c|}
\hline & レジン & 炭酸カルシウム粉 & 細骨 材 & 粗骨材 \\
\hline 打 被 前 & 0.221 & 0.109 & 0.241 & 0.429 \\
\hline 打 没 後 & 0.180 & 0.090 & 0.250 & 0.480 \\
\hline
\end{tabular}

表一2 レジンコンクリートの配合（容積係数）

\begin{tabular}{|c|c|c|c|}
\hline $\begin{array}{lrr}\text { 基 } & \text { 材 } \\
\left(\begin{array}{lll}\text { 不 } & \text { 飽 } & \text { 和 } \\
\text { ポリエステル }\end{array}\right)\end{array}$ & $\begin{array}{l}\text { 希 釈 剂 } \\
\left(\begin{array}{l}\text { スチレン } \\
\text { モノマー }\end{array}\right)\end{array}$ & 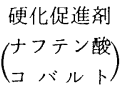 & 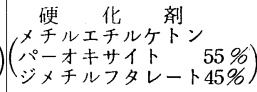 \\
\hline 1000 & 60 & 6 & 7 \\
\hline
\end{tabular}

表-3 レジンの成分とその配合（重量比）

荷日数の相違とひずみ-時間曲線との関係を調べ, 筆者 らの提案するレオロジー解析の妥当性を検討するために 行った。

レジンコンクリートは初期に高温養生することで，そ の特性を完全に安定させることができる。しかも，レジ ンペーストはその圧縮強度に比較して弾性係数が 小さ く，また，前記のセメントコンクリートのような問題点 も生じないため, 特化遅延弾性変形に関する筆者らの考 えを立証するには好都合な材料である。

表一1 に使用材料の比重を, 表一 2 と表一 3 亿材料分 離と打込みやすさとを考虑して決定したレジンコンクリ 一トの配合を示す。実験に用いた $\phi 7.5 \times 15 \mathrm{~cm}$ 円柱供 試体は, 材令 3 日で温度 $70^{\circ} \mathrm{C}$, 養生時間 6 時間の高温養 生を行い，その後，養生時の 残留ひずみを除去するた め, 4 日間恒温室内 (温度 $21^{\circ} \mathrm{C}$ 一定) に放置した ${ }^{7)}$ 。

材令 7 日で圧縮クリープ装置に供試体 2 本を 1 組とし てセットし, 破壊強度の約 $1 / 3$ に相当する一定圧縮応力 $\sigma=310 \mathrm{~kg} / \mathrm{cm}^{2}$ を油圧装置で載荷し，所定の日数で除荷 した後, 遅延弾性変形を測定した。ひずみ測定は使用粗 骨材の最大寸法（最大寸法 $20 \mathrm{~mm}$ ）および偏心載荷の影 響を考慮して，供試体中央対称 2 箇所に貼付した $70 \mathrm{~mm}$ ゲージを用い，静ひずみ計で行った。なお，同時に無載 荷供試体に貼付したゲージで零点移動を測定したが，そ の変化量は $\pm 10 \times 10^{-6}$ 程度であり，しかもその大半が 恒温室内の僅かな温度変化の影響によるものであった。 このようにレジンコンクリートの場合, 特にゲージの付

\begin{tabular}{l|c|c|c|c}
\multicolumn{6}{c}{ 表一4 レジンコンクリートの諸特性 } \\
\hline & $\begin{array}{c}\text { 単位重量 } \\
\left(\mathrm{t} / \mathrm{m}^{3}\right)\end{array}$ & $\begin{array}{c}\text { 圧縮強度 } \\
\left(\mathrm{kg} / \mathrm{cm}^{2}\right)\end{array}$ & 弾性係数 $\left(\times 10^{4} \mathrm{~kg} / \mathrm{cm}^{2}\right)$ \\
\cline { 4 - 5 } & 2.48 & 1010 & 初期係数 & 割線係数 \\
\hline コンクリート & 2.43 & 30.6 \\
モル タ ル & 2.11 & 1220 & 23.9 & 22.8 \\
ペースト & 1.73 & 1570 & 11.1 & 10.8 \\
\hline
\end{tabular}


着効果が良好であるため，長

期測定も可能であり, 測定精 度自体も高いものと考えられ る。

表一4 にコンクリート，モ ルタルおよびペースト（増量 材としての炭酸カルシウム粉 末を含む。）の諸特性を示す。 なお，本実験に用いたレジンは硬化時に大 きな容積収縮を生じ，しかも打設時には練 り板などにも付着するため, 硬化後の供試 体中に占めるレジン容積は配合計算の值と 相違することになる。そこで筆者らはレジ ンの容積収縮を調べるため, 硬化前後の比 重測定を行った。その結果, レジンの容積 収縮ひずみは $8.3 \%$ で，また，骨材が収縮 しないと考えたときのコンクリートの硬化 収縮ひずみは $0.61 \%$ であった。以上の点 と表一4 に示すコンクリート，モルタルお よびペーストの単位重量から，レオロジー 解析の数值計算に用いる硬化後の容積係数 を求めた。その結果を表一2に示す。

\section{2 実験結果および考察}

遅延弾性変形の機構を調べるため, 特に 載荷日数の相違とひずみ-時間曲線との関 係を求めたが，その結果を 図一5，表一5 に示す。図に示すように高温養生したレジ ンコンクリートのクリープはその大半が回 復変形, すなわち, 遅延弾性変形である。ただし, 載荷 日数の増加に伴い，僅かずつではあるが，明らかに永久 変形が増大する傾向が見られる。なお, 載荷時にも弾性 変形の $10 \%$ 程度の塑性変形を生ずるが, これは載荷時 に高応力を受ける骨材の内部ひびわれ伝播や骨材マトリ ックス界面における塑性的ずれによるものと考えられ る。

つぎに, 遅延弾性変形は載荷日数と密接に関連し, そ の変形成分が載荷期間中に発達することがわかる。ま た, そのひずみ一時間曲線も載荷日数で相違し, 特にそ の変形が急速成分だけから成ると考えられる 2 日間載荷 の場合は, 除荷後も急速に安定するが，7 日間以上の場 合は, 除荷後 1 日程度で安定するような急速成分と, そ の後徐々に回復する成分とを含み, 安定状態に達するま でには相当な日数を要するものと考えられる。なお, 表 -5 に示すように 7 日間以上載荷した場合にも僅かでは あるが，載荷日数の増加に伴い遅延弾性係数が増加する 傾向を示す。
表一5 クリープ実測結果

\begin{tabular}{|c|c|c|c|c|c|}
\hline $\begin{array}{l}\text { 除荷時の } \\
\text { 弾性ひずみ } \\
\varepsilon_{r}\left(\times 10^{-6}\right)\end{array}$ & 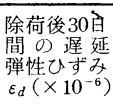 & $\varepsilon_{i} / \varepsilon_{r}$ & $\varepsilon_{c} / \varepsilon_{r}$ & $\varepsilon_{d} / \varepsilon_{r}$ & $\left(\varepsilon_{c}-\varepsilon_{d}\right) / \varepsilon_{,}$ \\
\hline 933 & 132 & 1.09 & 0.188 & 0.141 & 0.047 \\
\hline 870 & 183 & 1.10 & 0.260 & 0.210 & 0.051 \\
\hline 929 & 207 & 1.10 & 0.294 & 0.223 & 0.071 \\
\hline 942 & 212 & 1.11 & 0.311 & 0.225 & 0.086 \\
\hline 886 & 205 & 1.10 & 0.351 & 0.231 & 0.120 \\
\hline
\end{tabular}

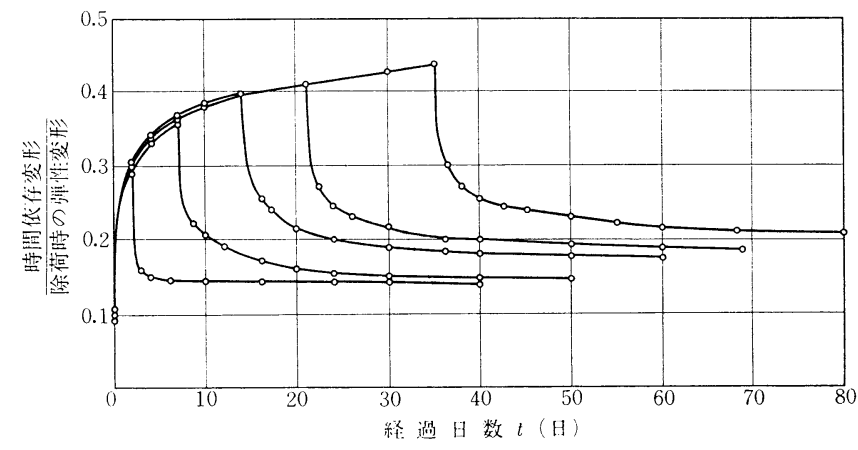

図一5＼cjkstart実測クリープ曲線

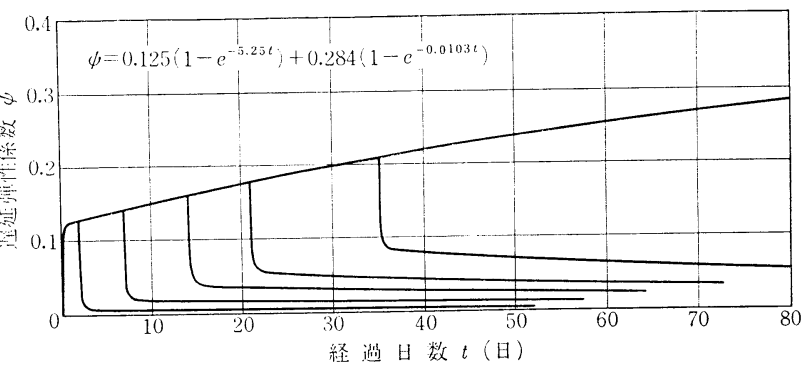

図一6回転モデル II による解析曲線

\section{3 実測曲線とレオロジー解析との比較検討}

レオロジー解析に用いるバネ定数 $G$ と腕の長さ $l$ と は，コンクリート複合体構成物質の弾性係数 $E$ とその 容積係数 $V$ とから定まるが，回転ダッシュポットの粘 性係数 $\eta$ は, 実測曲線との対応から試算的に求めなけれ ばならない。なお, 前記のモデル解析において, 筆者ら はコンクリートを細・粗骨材およびペーストからなる弾 性三要素体と考えたので，レオロジー解析に関しては回 転モデルII を適用した。

回転モデルIIの解析に用いた各要素の值, および解析 結果を下記に示す。なお, 計算を簡単にするため, バネ 定数 $G_{1}$ を基準值とした。

$$
\begin{aligned}
& l_{1}=V_{s}=0.250, l_{2}=V_{p}=0.270 \\
& l_{3}=V_{g}=0.480, l_{4}=l_{1}+l_{2}=0.520 \\
& G_{1}=V_{p} E_{p}=0.270 \times 11.1 \times 10^{4}=3.00 \times 10^{4}=1.00 \mathrm{G} \\
& G_{2}=V_{s} E_{s}=0.250 \times 38.4 \times 10^{4}=9.60 \times 10^{4}=3.20 \mathrm{G} \\
& G_{3}=V_{g} E_{g}=0.480 \times 44.2 \times 10^{4}=21.2 \times 10^{4}=7.08 \mathrm{G} \\
& \eta_{1}=0.05 \mathrm{G}, \eta_{2}=200 \mathrm{G}
\end{aligned}
$$


表一6 遅延弾性係数 $\psi$ の実測值と理論值との比較

\begin{tabular}{|c|c|c|c|c|c|c|c|c|c|c|c|c|}
\hline \multicolumn{3}{|c|}{ 除荷後の日数 } & $1 / 4$ & $1 / 2$ & 1 & 2 & 5 & 7 & 10 & 20 & 30 & $\infty$ \\
\hline \multirow{5}{*}{ 实测值 } & \multirow{5}{*}{ 載 } & 2 & 0.092 & 0.110 & 0.120 & 0.126 & 0.134 & 0.135 & 0.138 & 0.141 & 0.142 & - \\
\hline & & 7 & 0.091 & 0.109 & 0.126 & 0.144 & 0.165 & 0.173 & 0.182 & 0.203 & 0.210 & - \\
\hline & & 14 & 0.090 & 0.109 & 0.123 & 0.149 & 0.179 & 0.197 & 0.204 & 0.216 & 0.223 & - \\
\hline & & 21 & 0.091 & 0.113 & 0.136 & 0.157 & 0.183 & 0.193 & 0.207 & 0.221 & 0.225 & - \\
\hline & & 35 & 0.090 & 0.110 & 0.136 & 0.163 & 0.191 & 0.199 & 0.215 & 0.230 & 0.231 & - \\
\hline \multirow{6}{*}{$\begin{array}{l}\text { モデル II } \\
\text { の理論値 }\end{array}$} & \multirow{3}{*}{ 荷 } & 2 & 0.091 & 0.116 & 0.124 & 0.125 & 0.125 & 0.125 & 0.126 & 0.126 & 0.126 & 0.127 \\
\hline & & 7 & 0.091 & 0.116 & 0.124 & 0.125 & 0.126 & 0.127 & 0.128 & 0.130 & 0.131 & 0.145 \\
\hline & & 14 & 0.092 & 0.117 & 0.125 & 0.126 & 0.127 & 0.128 & 0.129 & 0.133 & 0.136 & 0.163 \\
\hline & \multirow{3}{*}{ 日 } & 21 & 0.092 & 0.117 & 0.125 & 0.127 & 0.128 & 0.129 & 0.131 & 0.136 & 0.142 & 0.180 \\
\hline & & 35 & 0.092 & 0.118 & 0.126 & 0.128 & 0.130 & 0.132 & 0.134 & 0.143 & 0.151 & 0.211 \\
\hline & & $\infty$ & 0.092 & 0.118 & 0.127 & 0.131 & 0.139 & 0.145 & 0.153 & 0.178 & 0.200 & 0.409 \\
\hline \multirow{6}{*}{$\begin{array}{l}\text { モデル III } \\
\text { の理論值 }\end{array}$} & \multirow[t]{6}{*}{ 数 } & 2 & 0.075 & 0.095 & 0.109 & 0.120 & 0.136 & 0.140 & 0.145 & 0.148 & 0.149 & 0.151 \\
\hline & & 7 & 0.078 & 0.102 & 0.122 & 0.143 & 0.173 & 0.183 & 0.191 & 0.196 & 0.198 & 0.208 \\
\hline & & 14 & 0.079 & 0.104 & 0.125 & 0.149 & 0.183 & 0.195 & 0.204 & 0.211 & 0.216 & 0.234 \\
\hline & & 21 & 0.079 & 0.105 & 0.126 & 0.150 & 0.185 & 0.198 & 0.207 & 0.219 & 0.222 & 0.246 \\
\hline & & 35 & 0.079 & 0.105 & 0.127 & 0.151 & 0.187 & 0.200 & 0.209 & 0.220 & 0.224 & 0.270 \\
\hline & & $\infty$ & 0.079 & 0.105 & 0.127 & 0.151 & 0.193 & 0.208 & 0.220 & 0.246 & 0.262 & 0.409 \\
\hline
\end{tabular}

[ここに， $E_{s}, E_{g}$ は式 (4)，式 (5) から求めた骨材 の見掛け弾性係数であるが，モルタルの容積係数 はレジンの硬化収縮と単位重量とを考慮して， $V_{p}$ $=0.300, V_{s}=0.265$ として計算した。

なお，上記の $\eta$ 值は実測曲線の傾きから求めた值であ る。

以上の数值を式 (20) に代入すると, 遅延弹性係数 は $\psi=0.125\left(1-e^{-5.25 t}\right)+0.284\left(1-e^{-0.0103 t}\right)$

となる。ただし， $t$ は日単位である。

解析曲線を 図一6 に, 実測值との比較を 表一6 に示 す。

図一6 からわかるように解析曲線の安定状態は実測曲 線のそれと多少相違する。すなわち, 解析曲線が急速に 安定するのに対し, 実測曲線は 1 日以後も緩やかに回復 している。表一6にもその相違が明確に見られ, 特に長 期載荷の場合, 遅延弹性係数が大幅に相違することから もうかがい知ることができる。

さて, 筆者らは以上のような相違点が解析計算に用い た粘性係数 クの取り方に原因するものと考えた。すなわ ち, 回転モデルIIは粗骨材の回転再配列に関する要素と して, 単に実測曲線の傾きから $\eta_{2}=200 G$ と決定した が，実際の現象は骨材の形状寸法でその再配 列の状態が異なるものと考えられるので，筆 者らは粗骨材をさらに $10 \mathrm{~mm}$ 寸法で分割 し，それらに対する粘性係数が相違すると考 え，新たに回転モデルIIIを用いて解析を行っ てみた。

以下に, 回転モデルIIII解析に用いた各要 素の值, および解析結果を示す。なお， $l_{3}$ は $10 \mathrm{~mm}$ ふるいを通る粗骨材の容積係数, $l_{5}$ は $10 \mathrm{~mm}$ ふるいに留まる粗骨材のそれであり,
ふるい分け試験の結果からそれらの值を定めた。

$$
\begin{array}{ll}
l_{1}=V_{s}=0.250 & l_{2}=V_{p}=0.270 \\
l_{3}=V_{g_{1}}=0.190 & l_{4}=l_{1}+l_{2}=0.520 \\
l_{5}=V_{g_{2}}=0.290 & l_{6}=l_{3}+l_{4}=0.710
\end{array}
$$

$G_{1}=V_{p} E_{p}=0.27 \times 11.1 \times 10^{4}=3.00 \times 10^{4}=1.00 \mathrm{G}$

$G_{2}=V_{s} E_{s}=0.250 \times 38.4 \times 10^{4}=9.60 \times 10^{4}=3.20 \mathrm{G}$

$G_{3}=V_{g_{1}} E_{g}=0.190 \times 44.2 \times 10^{4}=8.40 \times 10^{4}=2.80 \mathrm{G}$

$G_{4}=V_{g_{2}} E_{g}=0.290 \times 44.2 \times 10^{4}=12.82 \times 10^{4}=4.28 G$ $\eta_{1}=0.05 G, \eta_{2}=2.5 G, \eta_{3}=200 \mathrm{G}$

以上の值を式 (22) に代入すると, 遅延弾性係数 ঋ は

$$
\psi=0.095\left(1-e^{-5.30 t}\right)+0.112\left(1-e^{-0.311 t}\right)
$$$$
+0.202\left(1-e^{-0.0106 t}\right)
$$

となる。

図一7, 表一6 から明らかなように解析結果は回転乇 デルII対する值よりさらに実測值に近づき, 回転モデ ル正を用いれば，ほぼ完全に遅延弾性変形の特性を示し 得ることがわかる。

以上，レジンコンクリートに関する実測曲線と筆者ら の提案したレオロジーモデルによる理論曲線との比較検 討を行ったが，その結果は十分満足できるものであり， 遅延弾性変形が粒状複合体内部の弾性係数差に起因する

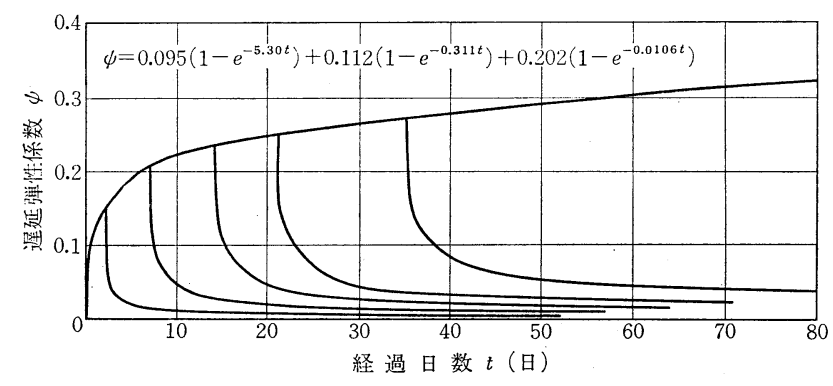

図一7 回転モデル III による解析曲線 
時間依存変形であることを明確に立証したものと考え る。

\section{5.まとめ}

粒状複合体の変形特性を究明するための基礎的研究と して, 遅延弾性変形に関する新たなレオロジ一解析法の 提案と, その解析法の妥当性を検討するためのレジンコ ンクリートに関する実験的研究を述べてきたが，以上の 研究結果を要約すると下記のと扝りである。

（1）高温養生したレジンコンクリートの初期クリー プはその大半が遅延弾性変形である。

（2）コンクリートの遅延弾性変形は各構成物質の弹 性係数差に起因する時間依存変形である。

（3）レジンコンクリートの遅延弾性変形は筆者らの 提案した回転モデル IIIで十分に表すことができた。

以上，コンクリートの遅延弾性現象に関する筆者らの 考えとその解析法を述べてきが，浅学なる筆者らの本 研究に対し広く各位のご批判, ご叱正を仰ぐ次第であ
る。

最後に本研究に際し, ご協力いただきました九州産業 大学工学部 山崎竹博助手, ならびに亀井頼隆副手に心 から謝意を表します。

\section{参 考 文 献}

1）宮川邦彦：段階的圧繀荷重を受けるコンクリートのクリ 一プについ, 土木学会第 25 回年次学術溝演会講演集, 昭 和 45 年 11 月

2）宮川邦彦, 龟井頼隆 : コンクリートの遅延弾性变形に関 する実験的研究, 土木学会第 27 回年次学術講演会講演概 要集, 昭和 47 年 10 月

3) 宮川邦彦：コンクリートの革延弾性変形, 土木学会第 30 回年次学術講演会講演概要集, 昭和 50 年 10 月

4) T.C. Hansen : Influence of Aggregate and Voids on Modulus of Elasticity of Concrete, Cement Mortar and Cement Paste. Journal of A.C.I Vol. 62

5) The Structure of Concrete, Cement and Concrete Association 1965 年発行

6）小野木重治：レオロジー要論, 梖書店

7）渡辺 明, 高山俊一, 山崎竹博: レジンコンクリートに 関する基礎的研究, 九州工業大学研究報告第 30 号, 昭和 50 年 3 月

(受理年月日：昭和 51 年 8 月 3 日) 